\title{
ANALISIS KANDUNGAN SAPONIN PADA DAUN DAN TANGKAI DAUN Carica pubescens Lenne \& K. Koch
}

\author{
Eko Budi Minarno
}

\author{
Jurusan Biologi Fakultas Saintek \\ Universitas Islam Negeri Maulana Malik Ibrahim Malang \\ Jl. Gajayana No.50, Malang, Indonesia \\ Email; budimminarno@yahoo.com
}

\begin{abstract}
Carica pubescens Lenne \& K. Koch is a tropical species that adapt to the plateau environment and low temperatures. In East Java, the plant is found in Cangar and Bromo region. Morphological, chemical content, and analysis of protein banding pattern on $C$. pubescens has been done, but more on the analysis of active compounds for pharmaceutical raw materials and its accumulation in the body of the plant has not been widely studied. Saponins on $C$. pubescens potential as a raw material of natural medicine in the treatment of Diabetes Mellitus (DM). This study aims to determine the content of saponin in leaf and petiole of $C$. pubescens in terms of absorbance values. Saponins were analyzed by qualitative form the foam test, color test, Thin Layer Chromatography (TLC) analytical and preparative. Quantitative test in the form of $U V$-Vis spectrophotometry results preparative TLC. This research was done at the Laboratory of Department of Biology and Chemistry UIN Maulana Malik Ibrahim Malang. The results showed that the leaf and petiole of $C$. pubescens positive for the saponins with the formation of stable foam for 60 seconds at 1.5 $\mathrm{cm}-1.7 \mathrm{~cm}$. The third positive samples containing saponins triterpene the ring test produces a brownish color. Isolation saponin by TLC shows the best ratio of eluent chloroform: methanol: water (14: 6: 1) compounds can be separated perfectly. Saponin absorbance values obtained three samples as follows: petiole samples from the region Cangar amounted to 0.852, leaf samples from the region Cangar amounted to 0.686, and leaf samples from Bromo region amounted to 0,629. The highest saponins found in organs petiole. Thus the petiole of $C$. pubescens has the potential to be used as a source of triterpene saponins which can be developed into a commercial herbal medicines.

Keywords: Carica pubescens Lenne \& K. Koch, Saponin Accumulation, Spectrophotometer, TLC
\end{abstract}

\section{PENDAHULUAN}

Carica pubescens Lenne \& K. Koch merupakan salah satu tanaman khas dataran tinggi. Di Indonesia, tanaman ini biasa dikenal dengan sebutan "karika", dapat dijumpai di kawasan Bromo dan Cangar Jawa Timur, serta Dataran Tinggi Dieng, Wonosobo-Banjarnegara Jawa Tengah. Carica pubescens merupakan anggota familia Caricaceae, sehingga memiliki kelompok Genus yang sama dengan Carica papaya dan memiliki kemiripan yang tinggi secara morfologi. Keberadaan rambut (pubescens) pada bagian abaksial dan tangkai daun menjadi penciri utama selain morfologi bunga, buah dan percabangan pada batang jika dibandingkan dengan morfologi Carica papaya. Selain itu, berkebalikan dengan Carica papaya, Carica pubescens tumbuh subur pada tempat dengan ketinggian 1.400-2400 meter di atas permukaan laut (dpl), temperatur rendah, dan curah hujan tinggi. Berikut morfologi $C$. pubescens ditunjukkan pada Gambar 1 .

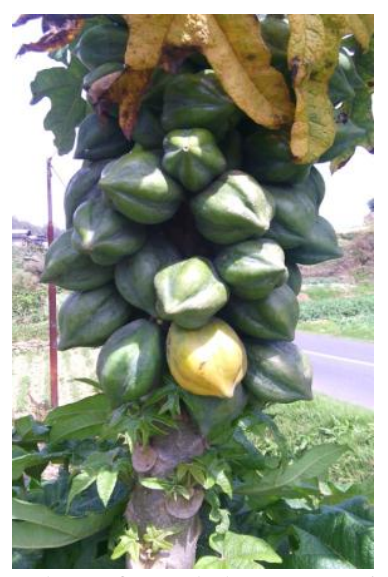

(sumber: foto dokumentasi pribadi) Gambar 1. Morfologi Carica pubescens 
Allah SWT telah menciptakan tumbuhtumbuhan yang baik sehingga dapat diambil manfaatnya oleh manusia sebagaimana tertulis dalam Al-Qur'an sebagai berikut:

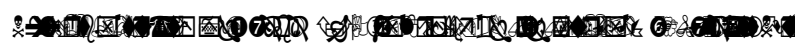

2010 2010

Artinya: "7. dan Apakah mereka tidak memperhatikan bumi, berapakah banyaknya Kami tumbuhkan di bumi itu pelbagai macam tumbuh-tumbuhan yang baik? 8. Sesungguhnya pada yang demikian itu benar-benar terdapat suatu tanda kekuasaan Allah. dan kebanyakan mereka tidak beriman. 9. dan Sesungguhnya Tuhanmu benar-benar Dialah yang Maha Perkasa lagi Maha Penyayang." (QS. Asy-Syu'araa: 7-9)

Studi mengenai tanaman obat dan potensinya untuk kesehatan dewasa ini banyak dikembangkan. Karakter morfologi, kapasitas antioksidan dan analisis pola pita protein terhadap C. pubescens telah dilakukan (Laily, 2011), akan tetapi lebih lanjut mengenai pemanfaatan senyawa aktif untuk bahan baku obat dan konservasinya belum banyak diteliti. Buah tanaman ini telah diteliti kandungannya sebagai sumber flavanoid (Minarno, 2014) sedangkan bijinya telah diteliti sebagai sumber saponin (Supono, 2014). Flavanoid erat kaitannya dengan aktivitas antioksidan sedangkan saponin merupakan senyawa dalam bentuk glikosida, keduanya tersebar luas pada tumbuhan.

Saponin membentuk busa yang mantap jika dikocok (Harbrone, 1987), merupakan golongan senyawa alam yang rumit, yang mempunyai massa dan molekul besar, dengan kegunaan luas (Burger, et.al., 1998). Struktur saponin menyebabkan saponin bersifat seperti sabun atau detergen sehingga saponin disebut sebagai surfaktan alami (nama saponin diambil dari sifat utama ini yaitu "sapo" dalam bahasa Latin yang berarti sabun) (Calabria, 2008; Hawley and Hawley, 2004). Contoh struktur saponin seperti ditunjukkan pada Gambar 2.

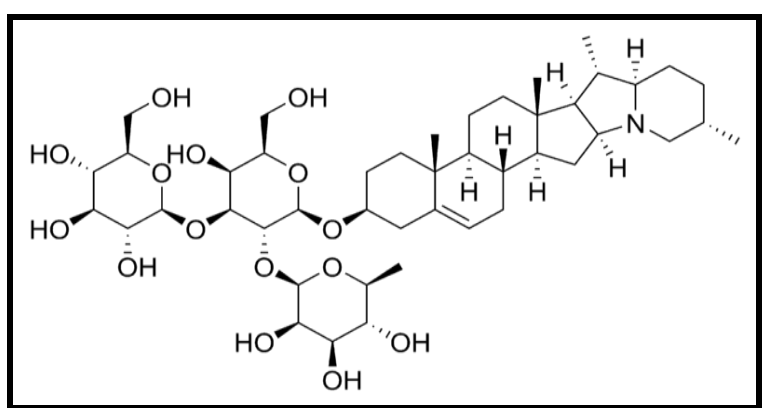

(sumber: http://isdha93.blogspot.com/2012/11/saponin.html)

Gambar 2. Contoh struktur saponin

Saponin termasuk senyawa fitokimia yang dapat menghambat peningkatan kadar glukosa darah dengan cara menghambat penyerapan glukosa di usus halus dan menghambat pengosongan lambung. Dengan melambatnya pengosongan lambung, maka absorpsi makanan akan semakin lama dan kadar glukosa darah akan mengalami perbaikan (Bruneton, 1999; Matsuda, et al., 1999; Mahendra dan Fauzi, 2005). Dengan demikian, saponin pada $C$. pubescens berpotensi sebagai herba bahan obat Diabetes Melitus.

Diabetes Mellitus (DM) adalah penyakit kelainan metabolik yang dikarakteristikkan dengan hiperglikemia kronis serta kelainan metabolisme karbohidrat, lemak dan protein diakibatkan oleh kelainan sekresi insulin, kerja insulin maupun keduanya (WHO, 2006). Hiperglikemia kronis pada diabetes melitus akan disertai dengan kerusakan, gangguan fungsi beberapa organ tubuh khususnya mata, ginjal, saraf, jantung dan pembuluh darah. Walaupun pada diabetes melitus ditemukan gangguan metabolisme semua sumber makanan tubuh kita, kelainan metabolisme yang paling utama ialah kelainan metabolisme karbohidarat. Oleh karena itu diagnosis DM selalu berdasarkan tingginya kadar glukosa dalam plasma darah (Adam, 2006).

Informasi mengenai organ tempat akumulasi saponin pada tanaman C. pubescens diperlukan dalam rangka pemanfaatan tanaman tersebut sebagai sumber saponin. Diperlukan pengetahuan tentang kandungan saponin pada daun maupun tangkai daun sebagai herba berpotensi obat pada kasus DM. Besarnya nilai absorbansi saponin pada spektrofotometri UVVis dapat digunakan sebagai rujukan untuk mengetahui perbandingan kandungan saponin pada organ tanaman. Dengan demikian penelitian ini perlu untuk dilakukan.

Penelitian ini bertujuan untuk mengetahui kandungan saponin pada daun dan tangkai daun 
C. pubescens. Hasil penelitian ini diharapkan dapat memberikan informasi tentang potensi senyawa saponin yang terkandung dalam berbagai organ tubuh tumbuhan $C$. pubescens yang tumbuh di Indonesia sebagai bahan baku obat DM. Pengetahuan tersebut dapat membantu masyarakat dan peneliti untuk memperoleh obat DM sekaligus mengkonservasi tanaman tersebut.

\section{METODE PENELITIAN}

Penelitian ini merupakan penelitian observasional dimana objeknya adalah $C$. pubescens yang tidak diberi perlakuan apapun tetapi dilakukan pemeriksaan kandungan saponin secara kualitatif dan kuantitatif sehingga data penelitian disajikan secara deskriptif.

Penelitian dilakukan pada bulan Agustus sampai dengan November 2015. Kegiatan pengambilan sampel Carica pubescens dilakukan di kawasan Cangar Batu dan Bromo, Jawa Timur. Analisis secara kualitatif maupun kuantitatif dilakukan di Laboratorium Fisiologi Tumbuhan Jurusan Biologi dan Laboratorium Kimia Organik Jurusan Kimia Fakultas Saintek UIN Maulana Malik Ibrahim Malang.

Alat-alat yang diperlukan untuk pengambilan sampel di lapangan serta analisis di laboratorium adalah: kamera dan kantong plastik oven, toples ekstraksi, pengaduk, pisau, saringan 60 mesh, rotary vacuum evaporator, hair dryer, spektrofotometer UV-VIS, tabung reaksi, gelas beker, gelas ukur, pipet mikro, neraca analitik, pipa kapiler, plat KLT, chamber KLT dan lampu UV.

Bahan-bahan yang diperlukan antara lain: C. pubescens (daun dari kawasan Cangar dan daun serta tangkai daun dari kawasan Bromo), kertas saring, methanol p.a., aquades, asam klorida $2 \mathrm{~N}$, kloroform, alkohol $95 \%$, asam asetat pekat anhidrat dan asam sulfat pekat.

a. Preparasi Sampel

1) Sampel C. pubescens diambil dari kawasan Cangar dan Bromo Jawa Timur

2) Sampel dibersihkan dari kotoran dan dikering anginkan

3) Ditimbang berat basah sampel

4) Dioven hingga kering kurang lebih selama 5-6 hari suhu $40{ }^{\circ} \mathrm{C}$.

5) Ditimbang berat kering sampel

6) Dihaluskan dan diayak menggunakan ayakan 60 mesh hingga menjadi simplisia serbuk b. Ekstraksi sampel

1) Maserasi dengan metanol p.a perbandingan 1:5 berat sampel

2) Disaring simplisia hingga didapatkan maserat pertama

3) Remaserasi dengan metanol p.a perbandingan 1:4 berat sampel

4) Disaring simplisia hingga didapatkan maserat kedua

5) Maserat diuapkan dengan rotary vacuum evaporator

6) Ekstrak diinkubasi pada suhu $27{ }^{\circ} \mathrm{C}$ hingga menjadi sediaan kental

c. Uji Pendahuluan

Uji kadar saponin secara kualitatif terdiri dari uji busa dan uji warna.

1) Uji busa

a) Ditimbang 0,3 gram ekstrak kemudian dimasukkan ke dalam tabung reaksi

b) Ditambahkan $10 \mathrm{ml}$ aquades kemudian dikocok kuat

c) Ditambahkan HCL 2N, diamati terbentuknya busa stabil selama kurang lebih 1 menit

2) Uji warna

a) Ditimbang ekstrak 0,3 gram dimasukkan ke dalam tabung reaksi

b) Ditambahkan $10 \mathrm{ml}$ kloroform

c) Dipanaskan di dalam inkubator selama 5 menit sambil dikocok/diaduk

d) Ditambahkan pereaksi LB hingga terbentuk cincin coklat pada permukaan tabung

d. Isolasi Saponin dengan KLT Analitik

1) Aktivasi plat KLT dengan dioven selama 1 jam suhu $100{ }^{\circ} \mathrm{C}$

2) Dibuat eluen dengan komposisi Kloroform:Methanol:Air perbandingan (13:7:2) dan (14:6:1)

3) Eluen dimasukkan dalam chamber sebanyak $10 \mathrm{ml}$

4) Penjenuhan eluen dalam chamber selama kurang lebih 1 jam

5) Ekstrak diencerkan $1000 \mathrm{ppm}$

6) Dipotong plat KLT ukuran $2 \times 10 \mathrm{~cm}$, diberi pembatas $1 \mathrm{~cm}$ untuk batas atas dan bawah plat

7) Ekstrak ditotolkan pada plat menggunakan pipa kapiler

8) Penotolan dilakukan sebanyak 5-8 kali, tiap sekali penotolan ditunggu hingga plat kering/ digunakan hair drayer

9) Plat dimasukkan dalam chamber dan ditunggu hingga plat terslusi sampai tanda batas atas 
10) Pembacaan hasil elusi dengan sinar UV $366 \mathrm{~nm}$

e. Isolasi Saponin dengan KLT Preparatif

1) Aktivasi plat KLT dengan dioven selama 1 jam suhu $100{ }^{\circ} \mathrm{C}$

2) Dibuat eluen dengan komposisi Kloroform:Methanol:Air perbandingan $(14: 6: 1)$

3) Eluen dimasukkan dalam chamber sebanyak $10 \mathrm{ml}$

4) Penjenuhan eluen dalam chamber selama kurang lebih 1 jam

5) Ekstrak diencerkan 1000 ppm

6) Dipotong plat KLT ukuran $5 \times 10 \mathrm{~cm}$, diberi pembatas $1 \mathrm{~cm}$ untuk batas atas dan bawah plat

7) Ekstrak ditotolkan pada plat menggunakan pipa kapiler

8) Penotolan dilakukan sebanyak 5-8 kali, tiap sekali penotolan ditunggu hingga plat kering/ digunakan hair drayer

9) Plat dimasukkan dalam chamber dan ditunggu hingga plat terelusi sampai tanda batas atas

10) Pembacaan hasil elusi dengan sinar UV $366 \mathrm{~nm}$

f. Pengukuran Senyawa Saponin dengan Spektrofotometri UV-Vis

Dari hasil KLT, warna yang sesuai dikerok. Hasil kerokan dimasukkan dalam tube kemudian ditambahkan methanol $1 \mathrm{ml}$, selanjutnya disentrifuge untuk memisahkan plat dengan supernatan. Supernatan yang didapat kemudian diukur absorbansi menggunakan spektro dengan panjang gelombang $209 \mathrm{~nm}$ dengan memasukkan isolat/supernatan ke dalam kuvet sebanyak 700 mikroliter.

Analisis data kandungan saponin dilakukan secara kualitatif dengan membandingkan busa dan warna sedangkan secara kuantitatif dilakukan dengan menentukan nilai absorbansi saponin terbaik dari ketiga sampel $C$. pubescens hasil pengukuran dengan spektrofotometri UV-Vis.

\section{HASIL DAN PEMBAHASAN}

Firdous, et al. (2009) membuktikan bahwa saponin berfungsi sebagai antidiabetes. Setelah dilakukan pemeriksaan histopatologi, diketahui bahwa saponin mampu meregenerasi pankreas yang menyebabkan adanya peningkatan jumlah sel $\beta$ pankreas dan pulau-pulau Langerhans sehingga sekresi insulin akan mengalami peningkatan. Peningkatan sekresi insulin tersebut akan membantu penurunan kadar glukosa darah. Regenerasi sel $\beta$ pankreas itu terjadi karena adanya sel quiescent pada pankreas yang memiliki kemampuan beregenerasi.

Beberapa contoh saponin pada tanaman antara lain diosgenin dan botogenin dari genus Dioscorea. Hekogenin, manogenin dan gitogenin dari spesies Agave. Sarsapogenin dan smilagenin dari genus Smilax. Sarmentogenin dari genus Strophantus. Sitosterol dari minyak tanaman. Famili Liliaceae, Amaryllidaceae dan Dioscoreaceae mengandung sapogenin. Demikian juga pada Apocynaceae (Sirait, 2007). Maka pada penelitian ini diselidiki kandungan saponin pada Genus Caricaceae, yakni $C$. pubescens pada dua organ tanaman dan dua tempat tumbuh yang berbeda di Indonesia.

\section{a. Penyiapan Ekstrak Carica pubescens Lenne \& K. Koch}

Pengambilan sampel buah dari dua tempat, yakni di Jawa Timur meliputi kawasan Cangar dan Bromo. Diperoleh sampel dari kawasan Cangar dengan berat basah daun sebesar 1117 gram dan tangkai daun dengan berat basah sebesar 1291 gram, sedangkan sampel dari kawasan Bromo yaitu daun dengan berat basah sebesar 1000 gram. Studi literatur telah dilakukan untuk mendapatkan metode ekstraksi, uji kualitatif dan kuantitatif sampel daun maupun tangkai daun $C$. pubescens.

Proses pengeringan sampel buah Carica pubescens Lenne \& K. Koch dilakukan dengan menggunakan oven dengan suhu $40{ }^{\circ} \mathrm{C}$ selama \pm 5-6 hari supaya zat yang diinginkan terlindung dari kemungkinan terjadinya kerusakan. Sampel yang telah dikeringkan selanjutnya dihaluskan dengan saringan 60 Mesh dan ditimbang untuk mengetahui berat kering dalam bentuk serbuk. Sampel dari kawasan Cangar mempunyai berat kering daun sebesar 220 gram dan tangkai daun dengan berat kering sebesar 50 gram, sedangkan sampel dari kawasan Bromo yaitu daun mempunyai berat kering sebesar 450 gram. Ekstrak diperoleh dengan mengekstraksi senyawa aktif dari simplisia menggunakan pelarut methanol pro analys. Metode yang diterapkan pada ekstraksi daun dan tangkai daun Carica pubescens Lenne \& K. Koch adalah metode maserasi. Maserasi buah dilakukan dengan proses pengekstrakan simplisia pada temperatur ruangan $\left(26{ }^{\circ} \mathrm{C}\right.$ sampai dengan 28 ${ }^{\circ} \mathrm{C}$ ), sehingga zat-zat yang terkandung di dalam simplisia relatif aman. Maserasi dilakukan 
dengan menggunakan perbandingan berat sampel:pelarut $=1: 5$ selama 24 jam. Selanjutnya remaserasi dilakukan dengan menggunakan perbandingan berat sampel:pelarut $=1: 4$ selama 24 jam. Selanjutnya ekstrak dipekatkan dengan rotary vacuum evaporator dan diinkubasi pada suhu $27{ }^{\circ} \mathrm{C}$ hingga menjadi sediaan kental. Dari proses ekstraksi, diperoleh sediaan kental dari kawasan Cangar sebesar 11 gram ekstrak daun dan 7,5 gram ekstrak tangkai daun, sedangkan dari kawasan Bromo diperoleh 16 gram ekstrak daun.

\section{b. Uji Pendahuluan Kandungan Saponin Ekstrak Carica pubescens Lenne \& K. Koch}

Uji pendahuluan untuk mengetahui kadar saponin secara kualitatif dilakukan dengan metode yang dideskripsikan oleh Suharto dkk (2012). Uji ini dilakukan untuk memastikan secara kualitatif adanya senyawa saponin yang terkandung dalam daun dan tangkai daun $C$. pubescens sampel dari kawasan Cangar dan daun sampel dari kawasan Bromo.

\section{Uji Busa}

Saponin bila dikocok akan membuih Kemampuan menurunkan tegangan permukaan ini disebabkan molekul saponin terdiri dari hidrofor dan hidrofil. Bagian hidrofob adalah aglikonnya, bagian hidrofil adalah glikonnya. Rasanya pahit atau getir. Sebagian besar saponin bereaksi netral (larut dalam air), beberapa ada yang bereaksi asam (sukar larut dalam air), sebagian kecil ada yang bereaksi basa. Aglikon saponin disebut sapogenin. Sapogenin sukar larut dalam air. Saponin dapat berupa senyawa yang mempunyai satu rantai gula atau dua rantai gula yang sebagian besar bercabang (Sirait, 2007).

Ekstrak kental C. pubescens sebanyak 0,3 gram dimasukkan dalam tabung reaksi. Dalam uji busa digunakan aquades sebagai pelarut dan asam klorida $2 \mathrm{~N}$ sebagai pereaksinya.

Pada ekstrak daun yang diperoleh dari kawasan Cangar, setelah ditambahkan $10 \mathrm{ml}$ aquades dan dikocok kuat kemudian dilakukan penambahan asam klorida $2 \mathrm{~N}$, terbentuk busa yang tidak hilang dengan ketinggian $1,5 \mathrm{~cm}$ selama kurang lebih 60 detik. Hasil uji busa pada sampel ekstrak daun dari kawasan Cangar seperti terlihat pada Gambar 3.

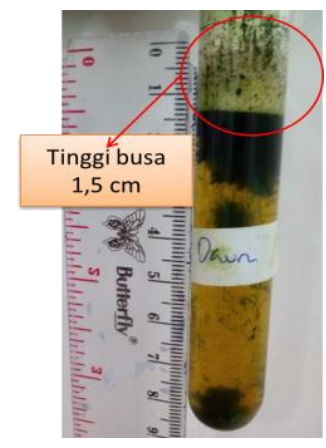

Gambar 3. Hasil uji busa pada sampel ekstrak daun dari kawasan Cangar

Pada ekstrak tangkai daun yang diperoleh dari kawasan Cangar, setelah ditambahkan 10 $\mathrm{ml}$ aquades dan dikocok kuat kemudian dilakukan penambahan asam klorida $2 \mathrm{~N}$, terbentuk busa yang tidak hilang dengan ketinggian 1,7 cm selama kurang lebih 60 detik. Hasil uji busa pada sampel ekstrak tangkai daun dari kawasan Cangar seperti terlihat pada Gambar 4.

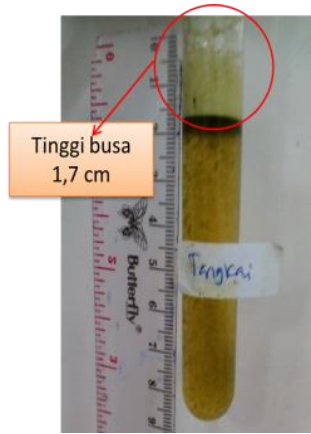

Gambar 4. Hasil uji busa pada sampel ekstrak tangkai daun dari kawasan Cangar

Pada ekstrak daun yang diperoleh dari kawasan Bromo, setelah ditambahkan $10 \mathrm{ml}$ aquades dan dikocok kuat kemudian dilakukan penambahan asam klorida $2 \mathrm{~N}$, terbentuk busa yang tidak hilang dengan ketinggian $1,5 \mathrm{~cm}$ selama kurang lebih 60 detik. Hasil uji busa pada sampel ekstrak tangkai daun dari kawasan Cangar seperti terlihat pada Gambar 5.

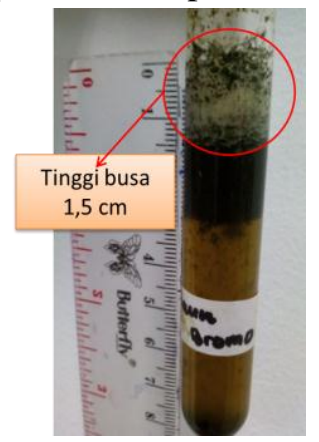

Gambar 5. Hasil uji busa pada sampel ekstrak daun dari kawasan Bromo 
Busa yang terbentuk dikarenakan senyawa saponin memiliki sifat fisika yaitu mudah larut dalam air dan akan menimbulkan busa ketika dikocok. Menurut Robinson (1995) senyawa yang memiliki gugus polar dan nonpolar bersifat aktif permukaan sehingga saat dikocok dengan air, saponin dapat membentuk misel. Pada struktur misel, gugus polar menghadap ke luar sedangkan gugus nonpolarnya menghadap ke dalam. Keadaan inilah yang tampak seperti busa.

\section{Uji Warna}

Uji warna yang dilakukan terhadap ketiga sampel menunjukkan hasil yang positif. Pada uji warna ini dapat pula diketahui golongan saponin yang terdapat pada ekstrak. Menurut Steinegger and Hansel (1992) dalam Sirait (2007), saponin dibagi menjadi 2 golongan:

a. Saponin sterol, bila terhidrolisis akan membentuk senyawa sterol

b. Saponin triterpen, bila terhidrolisis akan membentuk senyawa triterpen

Tschsche, Wollf, dan Gerlach dalam Sirait (2007) menyatakan bahwa saponin dibagi menjadi 3 golongan:

a. Saponin spirostanol

Disebut juga saponin netral. Contoh sarsasapogenin

b. Saponin triterpena

Disebut juga saponin asam. Contoh: asam oleanolat

c. Saponin sterol

Disebut juga saponin basa, dibagi menjadi dua tipe, yaitu:

1) Tipe demisin atau solanin, contoh: solanidin, solatubin.

2) Tipe tomatin, contoh tomatidin.

Saponin yang terdapat pada tumbuhan merupakan prekursor kortison maupun steroid.

Hasil uji warna pada sampel ekstrak daun

C. pubescens dari kawasan Cangar memperlihatkan hasil positif saponin. Warna cincin kecoklatan merupakan indikasi keberadaan saponin triterpen, sebagaimana terlihat pada Gambar 6.

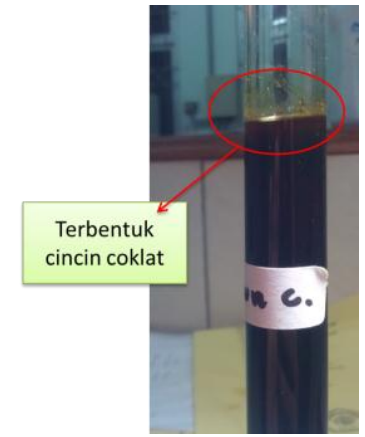

Gambar 6. Hasil uji warna pada sampel ekstrak daun dari kawasan Cangar

Berikutnya, hasil uji warna pada sampel ekstrak tangkai daun $C$. pubescens dari kawasan Cangar juga memperlihatkan hasil positif saponin. Warna cincin kecoklatan merupakan indikasi keberadaan saponin triterpen, sebagaimana terlihat pada Gambar 7.

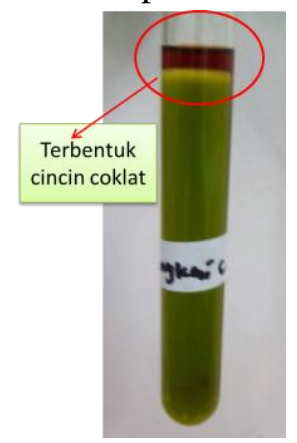

Gambar 7. Hasil uji warna pada sampel ekstrak tangkai daun dari kawasan Cangar

Demikian juga, hasil uji warna pada sampel daun C. pubescens dari kawasan Bromo dengan warna akhir ekstrak menyerupai sampel daun $C$. pubescens dari kawasan Cangar juga memperlihatkan hasil positif saponin. Warna cincin kecoklatan merupakan indikasi keberadaan saponin triterpen, sebagaimana terlihat pada Gambar 8 .

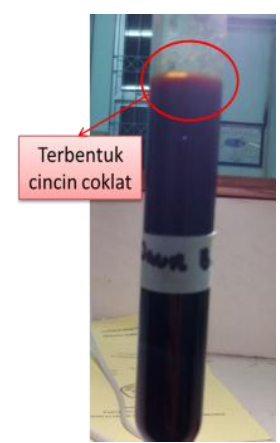

Gambar 8. Hasil uji warna pada sampel ekstrak daun dari kawasan Bromo 
Ketiga ekstrak dengan penambahan kloroform dan pereaksi LB menunjukkan warna yang berbeda pada ekstrak tangkai daun dari kawasan Cangar, yakni berwarna kehijauan sedangkan dua ekstrak lain lebih pekat kecoklatan. Namun demikian hasil akhir pada uji warna ketiga sampel menghasilkan warna yang sama, yaitu cincin kecoklatan pada permukaan tabung. Dengan demikian diketahui tiga sampel tersebut menunjukkan adanya saponin triterpen. Berdasarkan penelitian sebelumnya tentang senyawa saponin yang menyatakan bahwa sampel setelah ditambahkan pereaksi LB akan menghasilkan cincin warna coklat-ungu yang menunjukkan adanya saponin triterpen dan hijau-biru untuk saponin steroid.

\section{c. Isolasi Saponin dengan Kromatografi Lapis Tipis (KLT) Analitik}

Pemisahan senyawa saponin dari ekstrak C. pubescens dalam penelitian ini menggunakan metode KLT (Kromatografi Lapis Tipis). KLT merupakan metode yang sering digunakan untuk memisahkan komponen-komponen senyawa dalam suatu ekstrak. Perbandingan eluen yang baik diketahui berdasarkan uji coba di laboratorium. Hasil elusi dengan eluen kloroform:metanol:air (13:7:2) senyawa tidak terpisah dengan sempurna, terjadi tailing. Hasil tersebut dapat dilihat pada Gambar 9.

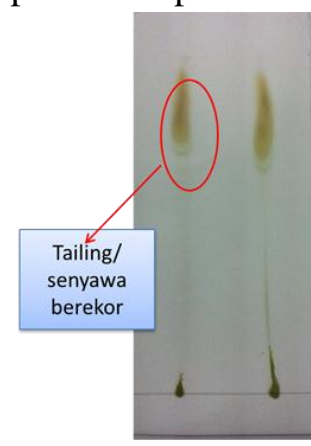

Gambar 9. Senyawa tidak terpisah sempurna dengan eluen kloroform:metanol:air (13:7:2)

Berikutnya diuji cobakan elusi dengan eluen kloroform:metanol:air (14:6:1) senyawa terpisah dengan sempurna. Dari hasil tersebut kemudian dilakukan penyinaran dengan lampu UV $366 \mathrm{~nm}$.

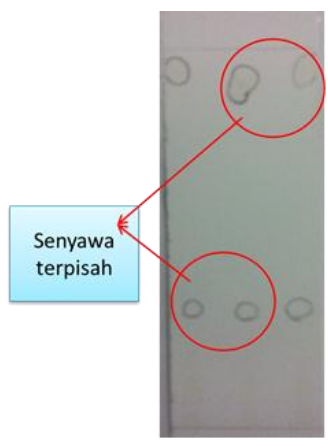

a

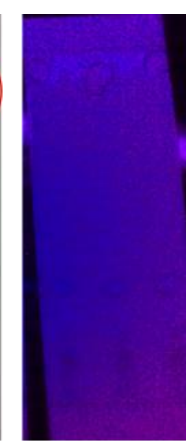

b
Gambar 10. Senyawa terpisah sempurna dengan eluen kloroform:metanol:air (14:6:1).

a. tanpa penyinaran lampu UV; b. dengan penyinaran lampu UV $366 \mathrm{~nm}$

\section{d. Isolasi Saponin dengan Kromatografi Lapis Tipis (KLT) Preparatif}

Hasil dari KLT analitik menunjukkan bahwa eluen terbaik yang dapat memisahkan senyawa pada ektrak C.pubescens adalah kloroform:metanol:air (14:6:1). Oleh karena itu eluen ini digunakan untuk KLT preparatif. Terdapat beberapa spot warna yang menunjukkan bahwa ekstrak mengandung beberapa senyawa. Hasil KLT sampel daun dari kawasan Cangar dapat dilihat pada Gambar 11.

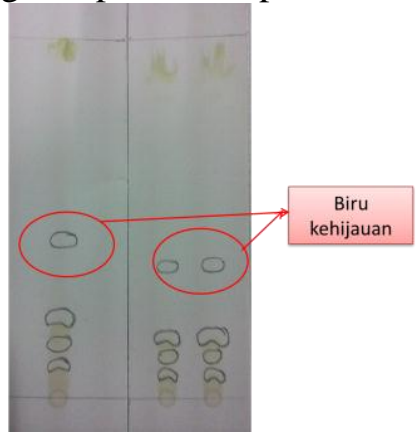

Gambar 11. Hasil KLT sampel daun dari kawasan Cangar

Pada ketiga sampel dilakukan penyemprotan pada plat dengan pereaksi LB yang dilanjutkan dengan pemanasan menggunakan hair drayer diperoleh bercak warna hijau kebiruan. Wagner dkk. (1984) menyatakan suatu simplisia dikatakan mengandung saponin apabila dilakukan penyemprotan dengan LB memberikan noda berwarna biru, biru violet, kadang merah atau kuning coklat pada sinar tampak. Nilai Rf yang diperoleh 0,275-0,375 (Suharto dkk., 2012). Hasil KLT sampel tangkai daun dari kawasan Cangar dapat dilihat pada Gambar 12. 


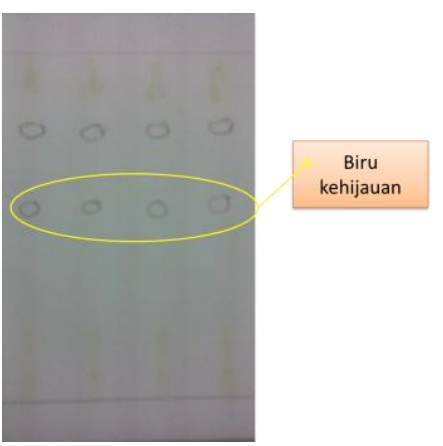

Gambar 12. Hasil KLT sampel tangkai daun dari kawasan Cangar

Selanjutnya, hasil KLT sampel daun dari kawasan Bromo dapat dilihat pada Gambar 13.

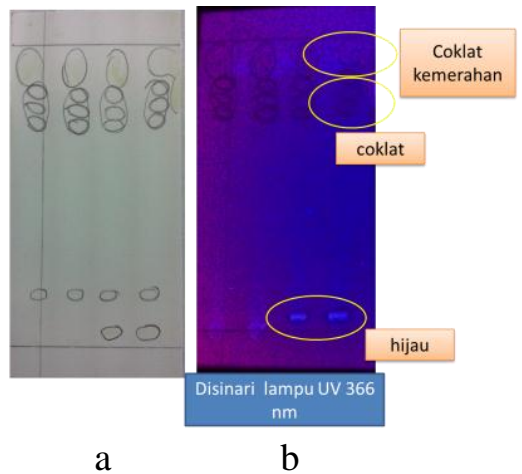

Gambar 13. Hasil KLT sampel daun dari kawasan Bromo; a. tanpa penyinaran lampu UV;

b. dengan penyinaran lampu UV $366 \mathrm{~nm}$

Pada sampel ini juga dilakukan pemeriksaan dengan penyinaran menggunakan lampu UV $366 \mathrm{~nm}$, tampak warna coklat kemerahan, coklat dan hijau untuk memperjelas pengamatan senyawa.

Berikut ini merupakan perbandingan hasil KLT ketiga sampel dengan perlakuan yang sama.

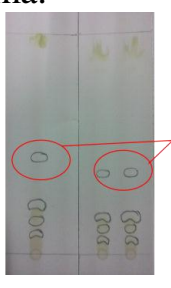

a

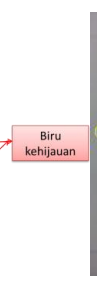

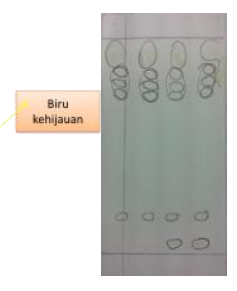

c
Gambar 14. Perbandingan hasil KLT ketiga sampel.

a. sampel daun dari kawasan Cangar; b. sampel tangkai daun dari kawasan Cangar; c. sampel daun dari kawasan Bromo

\section{e. Pengukuran Senyawa Saponin dengan} Spektrofotometri UV-Vis

Dari hasil Kromatografi Lapis Tipis preparatif kemudian warna yang sesuai dikerok sebagai isolat untuk diperiksa besarnya nilai absorbansi pada panjang gelombang $209 \mathrm{~nm}$ dengan spektrofotometer UV-Vis. Diketahui bahwa nilai absorbansi saponin pada tangkai daun dari kawasan Cangar sebesar 0,852; daun dari kawasan Cangar sebesar 0,686 dan daun dari kawasan Bromo sebesar 0,629. Dengan demikian tangkai daun dari kawasan Cangar memiliki nilai absorbansi saponin tertinggi.

Sirait (2007) menyatakan bahwa fitokimia menguraikan aspek kimia suatu tanaman. Kajian fitokimia meliputi:

1) Uraian tentang isolasi dan konstitusi senyawa kimia dalam tanaman

2) Perbandingan struktur senyawa kimia tanaman, berdasarkan definisi ini dilakukan penggolongan senyawa kimia yang ditemukan di alam

3) Perbandingan komposisi senyawa kimia dari bermacam-macam jenis tanaman atau penelitian untuk pengembangan senyawa kimia dalam tanaman (fitokimia perbandingan)

Fitokimia C. pubescens dan Caricaceae secara umum belum banyak dikaji, oleh karenanya perlu digali informasi berkelanjutan. Ditinjau dari proses pembuatan simplisia serbuk, nilai perbandingan berat basah dibanding berat kering serbuk adalah sebagai berikut: sampel daun dari kawasan Cangar sebesar 5,08; sampel tangkai daun dari kawasan Cangar sebesar 25,82 dan sampel daun dari kawasan Bromo 2,22. Hal ini menunjukkan kandungan air paling rendah terdapat pada sampel tangkai daun.

Rendahnya kandungan air dimungkinkan mempengaruhi metabolit sekunder yang terkandung dalam suatu organ tanaman. Sejalan dengan pendapat Sirait (2007), bahwa fisik tanaman sebagian besar terdiri atas air, kandungan air mencapai lebih dari $90 \%$ pada daun, bunga, buah (buah yang berair banyak) dan bagian tanaman yang berada di bawah tanah. Pada jaringan yang miskin organ penyimpanan, kandungan airnya menurun hingga sekitar $50 \%$ yaitu pada kulit dan kayu. Jaringan yang mengandung air paling sedikit adalah biji, umumnya mengandung $\pm 10 \%$. Senyawa kimia tanaman yang jumlahnya paling banyak adalah senyawa kimia bermolekul kecil dengan penyebaran terbatas, yaitu metabolit 
sekunder, termasuk dalam hal ini adalah kandungan saponin.

Dengan diketahui adanya saponin pada organ tanaman C.pubescens maka tanaman ini berpotensi dijadikan sebagai sumber bahan baku obat dalam pengobatan Diabetes Mellitus. Badan Kesehatan Dunia (WHO) menyebutkan bahwa $65 \%$ dari penduduk negara-negara maju telah menggunakan pengobatan tradisional (Depkes RI, 2008). WHO merekomendasikan penggunaan obat tradisional, termasuk herbal, dalam pemeliharaan kesehatan masyarakat, pencegahan dan pengobatan penyakit, terutama untuk penyakit kronis, penyakit degeneratif, serta kanker. WHO juga mendukung upayaupaya peningkatan keamanan dan khasiat obat tradisional (WHO, 2006). Penggunaan obat tradisional, secara umum dinilai relatif lebih aman daripada penggunaan obat modern, dengan catatan memenuhi kaidah dan aturan dalam penggunaannya. Sebab, obat tradisional memiliki efek samping yang relatif lebih sedikit dari pada obat modern dalam penggunaan yang tepat dan rasional (Purwanto, 2014).

Allah SWT adalah Dzat yang menciptakan segala penyakit, namun Dia juga yang menunjukkan metode penyembuhannnya. Sebagaimana yang disabdakan oleh Rasulullah SAW: "Allah tidak menurunkan penyakit kecuali Dia menurunkan obat baginya" (HR. Bukhari). Rasulullah SAW menegaskan bahwa setiap penyakit ada obatnya dan bisa disembuhkan atas izin Allah SWT, kecuali penuaan dan kematian. Sedangkan ragam obat sudah disediakan (diciptakan) oleh Sang Maha Penyembuh (Allah SWT). Begitu pula dengan teori dan praktik pengobatannya, secara garis besar maupun detail telah dicontohkan Rasulullah SAW. "Setiap penyakit itu memiliki obat, ketika obat itu mengenai penyakit maka ia sembuh atas izin Allah (HR. Muslim)".

Ibnu Qayyim al-Jauziyah mengatakan, bahwa ungkapan Nabi "setiap penyakit ada obatnya" memberikan semangat dan kekuatan jiwa orang yang sakit dan para dokter (tabib) yang mengobatinya, mereka terdorong untuk mencari obat dan menelitinya. Sedangkan bagi si pasien ketika merasa yakin bahwa pasti ada obat yang bisa menyembuhkan penyakitnya, maka ia memiliki semangat untuk sembuh. Rasa keputusasaan menjadi hilang karena harapan terbuka. Jika jiwanya sudah kuat, maka semangatpun meningkat, maka stamina yang mendukung tubuhnya juga meningkat sehingga mampu mengatasi bahkan mengusir penyakit.
Demikian juga bagi para dokter, jika sudah meyakini bahwa setiap penyakit pasti ada obatnya, ia pasti terus mencari obat dari suatu penyakit dan terus melakukan penelitian (AlJauziyah, 2013). Dengan demikian tidak terkecuali pada penelitian menggunakan $C$. pubescens sebagai sumber saponin dapat membuka wawasan baru pengobatan penyakit Diabetes Mellitus.

\section{KESIMPULAN}

Diperoleh kesimpulan bahwa tangkai daun memiliki nilai absorbansi saponin tertinggi. Tangkai daun $C$. pubescens memiliki potensi untuk dimanfaatkan sebagai sumber saponin triterpen yang dapat dikembangkan menjadi obat komersial alami.

\section{UCAPAN TERIMA KASIH}

Ucapan terima kasih kami sampaikan kepada LPPM UIN Maulana Malik Ibrahim Malang yang telah mendukung dan mendanai penelitian ini.

\section{DAFTAR PUSTAKA}

Adam, John. M. F. 2006. Klasifikasi dan Kriteria Diagnosis Diabetes Mellitus yang Baru. Cermin Dunia Kedokteran. 127: 3740.

Al-Jauziyah, Syekh Ibnu Qayyim. 2013. Rahasia Pengobatan Nabi SAW. Mitrapress.

Bruneton, J. 1999. Flavonoid. Dalam: Pharmacognosy: Phytochemistry medical plants, edisi 2. France: Lavoisier Publishing. p. 310-327.

Burger, I., Burger, B, V. Albrecht, C. F. Spicies, H. S. C. and Sandor. P. 1998. Triterpenoid saponin From Bacium gradivlona Var. Obovatum Phytochemistry. 49: 20872089.

Calabria, L. M. 2008. The Isolation and Characterization of Triterpene Saponins from Silphium and the Chemosystematic and Biological Significance of Saponins in The Asteraceae. ProQuest.

Departemen Kesehatan dan Kesejahteraan Sosial RI. 2008. Profil Kesehatan Indonesia 2007. Jakarta: Departemen Kesehatan RI.

Firdous, M., Koneri, R., Sarvaraidu, C. H. dan Shubhapriya, K. H. 2009. NIDDM 
Antidiabetic Activity of Saponins of Momordica Cymbalaria In StreptozotocinNicotinamide NIDDM Mice. Journal of Clinical and Diagnosis Research 3: 14601465.

Harbrone. J. B. 1987. Metode Fitokimia: Penuntun Cara Modern Menganalisis Tumbuhan. Terbitan Kedua. ITB: Bandung.

Hawley, Ts. and Hawley, R. G. 2004. Flow Cytometry Protocols. New York: Humana Press, Inc.

Laily, A. N. 2011. Karakterisasi Carica pubescens Lenne \& K. Koch Berdasarkan Karakter Morfologi, Kapasitas Antioksidan, dan Pola Pita Protein di Dataran Tinggi Dieng, Jawa Tengah. Tesis. Surakarta: Pascasarjana UNS.

Mahendra, B. dan Fauzi Rahmat Kusuma. 2005. Kumis kucing pembudidayaan dan Pemanfaatan untuk penghancur batu ginjal. Depok: Penebar Swadaya. 15: Hal 6-10.

Matsuda H., Li Y., Yamahara J., Yoshikawa M. 1999. Inhibition of Gastric Emptying by Triterpene Saponin, Momordin Ic, in Mice: Roles of Blood Glucose, CapsaicinSensitive Sensory Nerves and Central Nervous System. http://jpnet. aspetjournals.org/cgi/content/full/ 289/2/729. Diakses pada tanggal 25 Desember 2006.

Minarno, E. B. 2014. Skrining Fitokimia dan Kandungan Total Flavanoid pada Buah Carica pubescens Lenne \& K. Koch di Kawasan Bromo, Cangar dan Dataran Tinggi Dieng.

Purwanto, Budhi; editor, Hanifah Fitriani. 2014. Buku Ajar Ilmu Keperawatan Berbasis Herbal. Yogyakarta: D-Medika.

Robinson, T. 1995. Kandungan Organik Tumbuhan Tinggi. Edisi ke-4 Terjemahan Kosasih Padmawinata. Bandung: ITB Press.

Sirait, M. 2007. Penuntun Fitokimia dalam Farmasi. Bandung: Penerbit ITB.
Steinegger E. and Hansel R. 1992. Pharmakognosie. 5. Aufl. New York: Springer Verlag Heidelberg.

Suharto, M. A. P., Edy, H. J., Dumanauw, J. M. 2012. Isolasi dan Identifikasi Senyawa Saponin dari Ekstrak Methanol Batang Pisang Ambon (Musa paradisiaca var. sapientum L.). Parmachon Journal. I (2): 82-92.

Supono. 2014. Potensi Ekstrak Biji Karika (Carica pubescens) Sebagai Larvasida Nyamuk Aedes aegypty. El-Vivo. Vol 2, No 1.

Wagner, G. J. 1984. Characterization of a cadmium-binding complex of cabbage leaves. Plant Physiol. 76: 797-805.

World Health Organisation. 2006. Diabetes Mellitus: Report of a WHO Study Group. World Health Organisation. GenevaSwitzerland. S5-36. 